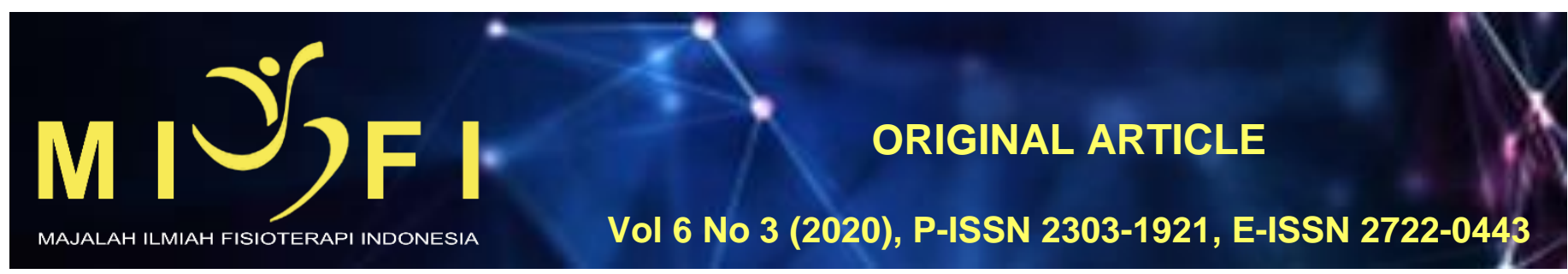

\title{
HUBUNGAN FLEKSIBILITAS LUMBAL DENGAN KESEIMBANGAN DINAMIS PADA LANSIA YANG MENGIKUTI SENAM LANSIA DI DESA SUMERTA KELOD DENPASAR TIMUR
}

\author{
${ }^{1}$ Made Eva Nata Putri, ${ }^{2}$ Anak Ayu Nyoman Trisna Narta Dewi, ${ }^{3}$ Ni Wayan Tianing, ${ }^{4} \mathrm{I}$ Made Niko Winaya \\ ${ }_{1}^{1}$ Program Studi Sarjana Fisioterapi dan Profesi Fisioterapi, Fakultas Kedokteran, Universitas Udayana,Denpasar,Bali \\ ${ }^{2,4}$ Departemen Fisioterapi, Fakultas Kedokteran, Universitas Udayana, Denpasar,Bali \\ ${ }^{3}$ Departemen Biokimia, Fakultas Kedokteran, Universitas Udayana, Denpasar,Bali \\ evanataputrii@gmail.com
}

\begin{abstract}
ABSTRAK
Seiring bertambahnya usia, terdapat berbagai perubahan fisiologis yang mempengaruhi tubuh, organ, sistem, dan penurunan fungsional sehingga dapat mengubah fungsi dan kemampuan tubuh yang akhirnya mengganggu aktivitas, kemandirian dan kualitas hidup. Penurunan aktivitas fisik lansia akan menyebabkan berkurangnya range of motion (ROM) dan kekuatan otot sehingga terjadi penurunan efektivitas dan fleksibilitas gerakan yang berdampak terhadap keseimbangan pada lansia. Senam lansia menjadi salah satu aktifitas olahraga yang diterapkan guna membantu menghambat penuaan yang kemudian berdampak pada kemampuan mobilitas lansia dalam menjaga keseimbangannya. Apabila fleksibilitas lumbal menurun, maka akan terjadi perubahan postural alignment pada pusat gravitasi tubuh yaitu adanya kompensasi pada pergeseran berat tubuh ke arah vertikal kedepan tumit sehingga tidak berada pada landasan penunjang. Keseimbangan dinamis merupakan kemampuan dalam menjaga postur tubuh tetap stabil ketika center of gravity (COG) mengalami perubahan yang memerlukan interaksi yang kompleks antara faktor pusat dan perifer seperti penglihatan, somatosensasi, output motorik, sensasi vestibular, dan otot-otot. Tujuan penelitian ini yaitu untuk mengetahui hubungan antara fleksibilitas lumbal dengan keseimbangan dinamis pada lansia yang mengikuti senam lansia. Penelitian ini adalah penelitian observasional analitik menggunakan desain cross sectional. Pengambilan sampel dilakukan dengan teknik purposive sampling. Sampel sebanyak 36 sampel lansia usia antara $60-$ 74 tahun dan telah dipilih berdasarkan kriteria inklusi dan eksklusi. Berdasarkan hasil uji statistik menggunakan Chi Square, nilai Asymptotic Significance (2-sided) atau p diperoleh sebesar 0,000. Terdapat hubungan antara fleksibilitas lumbal dengan keseimbangan dinamis pada lansia usia 60- 74 tahun yang mengikuti senam lansia di Desa Sumerta Kelod Denpasar Timur.
\end{abstract}

Kata kunci : fleksibilitas lumbal, keseimbangan, dinamis, senam lansia

\section{RELATIONSHIP BETWEEN LUMBAR FLEXIBILITY AND DYNAMIC BALANCE IN THE ELDERLY WHO JOIN THE ELDERLY GYMNASTIC IN SUMERTA KELOD DENPASAR TIMUR}

\section{ABSTRACT}

Aging in the elderly affects the body, organs, systems, and decreased functionalities that can change the functions and abilities of the body which are ultimately related to quality of life and independence. Decreased physical activity in the elderly will cause a decrease in range of motion (ROM) and muscle strength resulting in a decrease in efficiency and improvement in movement that affects the balance in the elderly. The application of physical training consisting of elderly exercise will increase the ability in maintaining balance. Reduce lumbar flexibility changes alignment postures such as compensation for future vertical transitions, no longer in the framework of support, and as a result all the required force is not equal to zero. Dynamic balance forms the ability to maintain a stable position while compiling the constantly changing center of gravity (COG). The purpose of this study is determine relationship between lumbar flexibility and dynamic balance in the elderly who follow elderly gymnastics. This study is an observational analytic study using cross sectional design. Sampling was done by purposive sampling technique. Total sample of 36 elderly samples aged between 60-74 years and selected based on inclusion and exclusion criteria. Based on the results of statistical tests using Chi Square, the value of Asymptotic Significance (2-sided) or $p$ was obtained at 0,000 . There is a relationship between lumbar flexibility and dynamic balance in the elderly aged 60-74 years who follow the gymnastics in the village of Sumerta Kelod, East Denpasar.

Key Words: lumbal flexibility, balance, dynamic, elderly gymnastic

\section{PENDAHULUAN}

Seiring bertambahnya usia, terdapat berbagai perubahan fisiologis yang terjadi. Perubahan ini mempengaruhi tubuh, organ, sistem, dan penurunan fungsional sehingga dapat mengubah fungsi dan kemampuan tubuh yang pada akhirnya mengganggu kemandirian dan kualitas hidup. ${ }^{1}$ Adanya penurunan aktivitas, kualitas hidup dan kemandirian pada lansia merupakan dampak dari perubahan fungsional yang terjadi. ${ }^{2}$

Berdasarkan data Riskesdas tahun 2013, individu yang berusia 65 tahun keatas dengan angka 37,4\% tergolong pada aktivitas fisik kurang aktif dan menempati urutan pertama. ${ }^{3}$ Penurunan aktivitas fisik pada lansia akan menyebabkan berkurangnya range of motion (ROM) dan kekuatan otot sehingga terjadi penurunan efektivitas gerakan 
pada punggung, hip dan ankle yang berdampak terhadap peningkatan resiko jatuh pada lansia. ${ }^{1}$ Maka dari itu, lansia perlu dilatih dengan aktivitas fisik yang tidak hanya murah dan mudah dilakukan, tetapi juga membantu lansia dalam mencapai fungsi keseimbangan dan kebugaran tubuh yang optimal. Olahraga yang meliputi gerakan pelatihan kelenturan serta kekuatan otot diperlukan untuk menjaga keseimbangan pada lansia. Berdasarkan pedoman tersebut, aktivitas fisik yang patut untuk direkomendasikan pada lansia yaitu senam lansia. ${ }^{4}$ Senam lansia menjadi salah satu aktifitas olahraga yang dapat diterapkan oleh lansia sebagai latihan fisik yang akan membantu untuk membiasakan dan menjaga pergerakan pada otot dan sendi yang kemudian berdampak pada kekuatan sendi dan otot sehingga terjadi peningkatan kemampuan mobilitas lansia. ${ }^{5}$ Menurut penelitian yang dilakukan Sheylla tahun 2015, menyatakan bahwa pada lansia yang tidak mengikuti senam dan mengikuti senam terdapat perbedaan yang signifikan dalam tingkat keseimbangan tubuhnya. ${ }^{6}$ Senam lansia meliputi gerakan pada tungkai, lengan dan trunk yang kemudian berdampak pada peningkatan kekuatan otot karena adanya kontraksi otot serta fleksibilitas sehingga kemampuan dalam mempertahankan keseimbangan membaik. ${ }^{4}$

Lansia secara fisiologis mengalami penuaan yang kemudian menghasilkan penurunan luas otot crosssectional dan volume jaringan ikat. Lebih jauh lagi, penurunan pada serabut otot fast twitch tipe II akan menghambat kemampuan otot untuk menciptakan kontraksi yang cepat dan kuat dalam mempertahankan keseimbangan. Perubahan fisiologis tersebut akan menghasilkan perubahan kinematik dari sistem muskuloskeletal. Adanya penurunan fleksibilitas ekstensor trunk sebesar 50\% akan menyebabkan perpindahan center of mass (COM) ke posterior tumit pada usia 70 tahun. ${ }^{1}$ Fleksibilitas yang baik akan membantu memberikan kemudahan dalam gerakan dan ROM yang lebih luas pada sendi, elastisitas otot, aktivitas fisik menjadi lebih efisien, mencegah terjadinya cedera, meningkatkan kualitas hidup dan kemandirian fungsional. ${ }^{7}$ Penurunan fleksibilitas dapat menyebabkan timbulnya masalah seperti kesulitan berjalan, kesulitan beraktivitas, kelemahan dan adanya nyeri. Respon keseimbangan yang efektif dapat terjadi apabila adanya fleksibilitas disertai dengan struktur mekanik yang cukup. Fleksibilitas berkurang akan menyebabkan efektifitas dan efisiensi dalam mempertahankan keseimbangan menurun. ${ }^{8}$

Keseimbangan dianggap sebagai komponen penting dalam beraktivitas sehari-hari, mulai dari kegiatan yang sederhana seperti berdiri sampai aktivitas yang lebih rumit seperti berjalan sambil berbicara atau ketika mengubah arah. Keseimbangan merupakan kemampuan tubuh dalam menjaga pusat gravitasi atau pusat masa tubuh terhadap landasan penunjang. World Health Organization (WHO) menyatakan, pada lansia angka jatuh mencapai 30-50\% dan presentase jatuh berulang sebesar $40 \%$, dan akan mengalami peningkatan sebesar $20 \%$ pada tahun 2050 . Peningkatan yang terjadi di tahun 2050 akan terjadi jika permasalahan keseimbangan tidak ditangani. ${ }^{9}$ Integrasi antara reaksi vestibular, sistem saraf dan visual diperlukan dalam menjaga keseimbangan untuk memproses informasi sensorik dan mengirim tanggapan motorik yang sesuai secara terus menerus. Keseimbangan dinamis diperlukan ketika melakukan aktivitas sehari hari. Keseimbangan dinamis berperan dalam mengontrol postur dan posisi tubuh agar tetap dalam posisi tegak dan akan tercipta koordinasi gerakan yang baik dan terarah. ${ }^{10}$

Berdasarkan uraian diatas maka peneliti ingin melihat hubungan antara fleksibilitas lumbal terhadap keseimbangan dinamis pada lansia yang mengikuti senam lansia.

\section{METODE}

Desain penelitian ini yaitu observasional analitik dengan pendekatan cross-sectional. Penelitian ini dilaksanakan di Desa Sumerta Kelod Denpasar Timur. Penelitian dimulai pada bulan Februari sampai dengan Maret 2020. Sampel pada penelitian ini berjumlah 36 orang.

Populasi target pada penelitian ini adalah lansia usia 60-74 tahun yang mengikuti senam lansia di Desa Sumerta Kelod Denpasar Timur. Pengambilan sampel dilakukan menggunakan teknik purposive sampling dengan cara mencari sampel yang memenuhi kriteria inklusi dan eksklusi dari peneliti hingga jumlah sampel yang diperlukan terpenuhi.

Kriteria inklusi penelitian ini adalah berjenis kelamin laki-laki dan perempuan, minimal mengikuti 2 kali senam lansia pada 1 bulan sebelum penelitian yang dilihat melalui absensi, mampu mengerti dan dapat berkomunikasi dengan baik, dan menandatangani informed consent yang disediakan peneliti untuk bersedia sebagai sampel serta secara sukarela sebagai subjek penelitian dari awal sampai akhir penelitian. Kriteria eksklusi penelitian ini adalah memiliki riwayat fraktur, cedera muskuloskeletal yang parah pada punggung dan ekstremitas bawah dan nyeri pada saat penelitian, serta memiliki gangguan sensoris (vestibular, visual, somatosensori) yang diperoleh melalui pemeriksaan oleh dokter umum. Fleksibilitas lumbal diukur menggunakan modified schober test (MST) dan keseimbangan dinamis diukur menggunakan four square step test (FSST)

Analisis data pada penelitian ini menggunakan software komputer dengan menggunakan uji deskriptif univariat dan uji statistik chi-square.

\section{HASIL}

Adapun karakteristik responden berdasarkan umur, nilai fleksibilitas lumbal yang berhubungan dengan keseimbangan dinamis dapat dilihat pada tabel 1.

Tabel 1. Distribusi Frekuensi Karakteristik Responden

\begin{tabular}{lcccc}
\hline Variabel & Frekuensi $(\mathrm{n})$ & Persentase $(\%)$ & Rerata \pm SB \\
\hline Usia & & & \\
& $60-64$ tahun & 9 & 33,3 & \\
& $65-69$ tahun & 9 & 25 & $66,39 \pm 4,789$ \\
70-74 tahun & 15 & 41,7 & \\
\hline $\begin{array}{l}\text { Fleksibilitas Lumbal } \\
\text { Normal }\end{array}$ & 30 & 83,3 & $1,17 \pm 0,378$
\end{tabular}


Berdasarkan Tabel 1, maka diketahui distribusi responden berdasarkan usia terbanyak pada usia 70-74 tahun yaitu sebanyak 15 responden (41,7\%), 60-64 tahun sebanyak 12 responden (33,3\%) dan 65-69 tahun sebanyak 9 responden (25\%). Distribusi berdasarkan fleksibilitas lumbal kategori normal yaitu sebanyak 30 responden $(83,3 \%)$ sementara fleksibilitas lumbal tidak normal sebanyak 6 responden (16,7\%). Distribusi berdasarkan keseimbangan dinamis kategori baik yaitu sebanyak 27 responden (75\%) sementara keseimbangan dinamis kategori buruk sebanyak 9 . Hubungan antara fleksibilitas lumbal dengan keseimbangan dinamis dilakukan menggunakan uji chi-square. Adapun data lengkap hasil dari uji chi-square dapat dilihat pada Tabel 2.

Tabel 2. Tabel silang hubungan fleksibilitas lumbal dengan keseimbangan dinamis

\begin{tabular}{|c|c|c|c|c|c|c|c|}
\hline \multirow{3}{*}{$\begin{array}{c}\text { Fleksibilitas } \\
\text { Lumbal }\end{array}$} & \multicolumn{4}{|c|}{ Keseimbangan Dinamis } & \multirow{2}{*}{\multicolumn{2}{|c|}{ Total }} & \multirow[b]{2}{*}{ p } \\
\hline & & & & & & & \\
\hline & $\mathrm{n}$ & $\%$ & $\mathrm{~N}$ & $\%$ & $\mathrm{n}$ & $\%$ & \\
\hline Normal & 26 & 72,2 & 4 & 11,1 & 30 & 83,3 & 0,0 \\
\hline Tidak Normal & 1 & 2,8 & 5 & 13,9 & 6 & 16,7 & \\
\hline Jumla & 27 & 75 & 9 & 25 & 36 & 100 & \\
\hline
\end{tabular}

Berdasarkan hasil penelitian pada tabel 2, untuk mengetahui ada atau tidaknya hubungan antara fleksibilitas lumbal dengan keseimbangan dinamis pada lansia di Desa Sumerta Kelod Denpasar Timur maka dilakukan pengujian dengan uji statistik Chi Square dengan nilai Asymptotic Significance (2-sided) atau p yang diperoleh sebesar 0,000. Dasar pengambilan keputusan yang digunakan adalah jika nilai Asymptotic Significance (2-sided) atau $p$ value lebih kecil dari 0,05, maka $\mathrm{H} 0$ ditolak dan Ha diterima, yang artinya terdapat hubungan antara kedua variabel. Berdasarkan hasil uji chi-square pada taraf kepercayaan $95 \%(\alpha \leq 0,05)$, didapatkan hasil $p$ value $=0,000$, dimana hasil $p$ value $<0,05$, sehingga $\mathrm{HO}$ ditolak dan $\mathrm{Ha}$ diterima, yang artinya terdapat hubungan terdapat hubungan antara fleksibilitas lumbal dengan keseimbangan dinamis pada lansia di Desa Sumerta Kelod Denpasar Timur.

\section{DISKUSI}

Responden pada penelitian ini menurut usia menunjukkan bahwa responden terbanyak ada pada usia 70-74 tahun yaitu 15 responden, usia 60-64 tahun sebanyak 12 responden dan yang berusia 65-69 sebanyak 9 responden. Fleksibilitas menurun seiring bertambahnya usia, terdapat penurunan fleksibilitas sebesar $20 \%$ hingga $30 \%$ antara usia 30 dan 70 tahun. Imobilisasi atau kurangnya aktivitas meningkatkan perputaran kolagen dan deposisi pada ligamen, memendekkan serat otot, dan mengurangi massa otot, sehingga mengurangi fleksibilitas. ${ }^{11}$

Berdasarkan nilai fleksibilitas lumbal pada penelitian ini, terdapat sebanyak 30 orang lansia memiliki fleksibilitas lumbal yang normal. Lansia di Desa Sumerta Kelod Denpasar Timur sebagian besar sudah tidak bekerja dan hanya beraktivitas dirumah maupun di lingkungan atau adat namun sebagian besar dari mereka juga rutin mengikuti senam lansia yang diadakan setiap minggu di masing-masing banjar. Data subjek pada penelitian ini memperlihatkan bahwa lansia yang memiliki fleksibilitas normal berjumlah lebih banyak yaitu 30 responden (83,3\%) dibandingkan yang tidak normal yaitu 6 responden (16,7\%). Hal tersebut kemungkinan dikarenakan aktivitas fisik sehari-hari dan kegiatan senam yang rutin mereka ikuti setiap minggunya. Sejalan dengan penelitian yang dilakukan oleh Percusha tahun 2017, dimana penelitian tersebut menyatakan senam lansia aerobic low impact berpengaruh terhadap peningkatan fleksibilitas lumbal pada lansia. ${ }^{12}$ Fleksibilitas memiliki sifat yang kompleks dimana tidak hanya melibatkan ROM sendi atau serangkaian sendi tetapi dipengaruhi juga oleh faktor internal seperti jenis sendi, elastisitas jaringan otot, tendon, ligamen, dan kulit dan juga oleh faktor eksternal seperti usia, tahap dalam proses pemulihan sendi dan aktivitas fisik. ${ }^{7}$ Pada penelitian Yanti tahun 2017, menyatakan aktivitas fisik memiliki hubungan dengan fleksibilitas punggung pada lansia. Dari penelitian tersebut menyatakan bahwa lansia yang secara rutin beraktifitas fisik memilikinfleksibilitas punggung yang baik. ${ }^{13}$ Serupa pula dengan penelitian dari Stathokostas tahun 2013 dimana dalam penelitiannya menemukan lansia aktif memiliki nilai fleksibilitas lebih baik dibandingkan lansia yang tidak aktif. ${ }^{14}$ Adanya penurunan fleksibilitas pada lansia dapat menyebabkan timbulnya masalah seperti kesulitan berjalan, kesulitan beraktivitas, kelemahan dan adanya nyeri. Respon keseimbangan yang efektif dapat terjadi apabila adanya fleksibilitas disertai dengan struktur mekanik yang cukup. Penurunan fleksibilitas dapat menyebabkan penurunan efektifitas dan efisiensi dalam mempertahankan keseimbangan. ${ }^{8}$

Karakteristik responden berdasarkan keseimbangan dinamis memperlihatkan bahwa responden lansia pada penelitian ini lebih banyak memiliki keseimbangan dinamis kategori baik yang diukur menggunakan FSST dengan jumlah sebanyak 27 responden (75\%). Penurunan fungsi fisiologis yaitu keseimbangan dapat dihambat penurunannya dengan melakukan aktivitas fisik olahraga rutin seperti senam lansia, dimana responden pada penelitian ini rutin mengikuti senam lansia yang diadakan di masing-masing banjar setiap minggunya sehingga responden yang memiliki nilai keseimbangan dinamis kategori baik berjumlah lebih banyak dibandingkan yang memiliki kategori keseimbangan dinamis buruk. Menurut penelitian oleh Lanawati tahun 2015, senam kesegaran jasmani lansia dapat menghambat gangguan keseimbangan tubuh pada lansia. Proporsi lansia yang mempunyai nilai fungsi kognitif normal lebih besar pada lansia yang rutin mengikuti senam lansia serta memiliki keseimbangan tubuh yang baik. ${ }^{5}$ Penelitian tersebut didukung juga dengan penelitian yang dilakukan oleh Wijianto tahun 2013 menyatakan bahwa senam lansia berpengaruh terhadap keseimbangan tubuh $(p=0,01) .{ }^{16}$ 
Keseimbangan dinamis didefinisikan sebagai kemampuan untuk mempertahankan stabilitas selama pemindahan berat badan ketika terjadi perubahan landasan penunjang. ${ }^{17}$ Kemampuan untuk mengontrol keseimbangan memburuk seiring bertambahnya usia sebagai akibat dari penurunan fungsi dalam sistem saraf vestibular, visual, somatosensori, muskuloskeletal, dan pusat. Sebagai akibatnya, populasi lansia menunjukkan gangguan dalam stabilitas dan keseimbangan sehingga meningkatkan risiko jatuh dalam situasi statis dan dinamis. ${ }^{17}$ Penuaan biologis menyebabkan perubahan struktural dan berkurangnya kapasitas fungsional, dimana terjadi penurunan langsung pada keseimbangan dan berjalan. Stabilitas trunk yang cukup dan kontrol gerakan sangat penting dalam keseimbangan dan gaya berjalan normal, hal itu karena tubuh bagian atas merupakan dua pertiga dari total berat badan. ${ }^{18}$

Perubahan pada sistem muskuloskeletal yaitu daya tahan, kekuatan otot dan fleksibilitas akan mempengaruhi sistem keseimbangan. Sistem muskuloskeletal bergerak secara stimulan dan sinergis sehingga mampu menerima daya yang ada. Ketika mempertahankan keseimbangan, otot-otot sekitar sendi akan bekerja dan selanjutnya kontrol postural akan berperan dalam mencapai keseimbangan. ${ }^{8}$

\section{Hubungan fleksibilitas lumbal dengan keseimbangan dinamis pada lansia yang mengikuti senam lansia}

Data subjek pada penelitian ini memperlihatkan bahwa lansia yang memiliki fleksibilitas normal berjumlah lebih banyak yaitu 30 responden (83,3\%) dibandingkan yang tidak normal yaitu 6 responden (16,7\%). Begitu pula dengan keseimbangan dinamis yang memperlihatkan bahwa responden lansia pada penelitian ini lebih banyak memiliki keseimbangan dinamis kategori baik yang diukur menggunakan FSST dengan jumlah sebanyak 27 responden (75\%). Hal tersebut kemungkinan dikarenakan aktivitas fisik sehari-hari dan kegiatan senam lansia yang diikuti. Didukung dengan penelitian Percusha tahun 2017, dimana penelitian tersebut menyatakan senam lansia aerobic low impact berpengaruh terhadap peningkatan fleksibilitas lumbal pada lansia.

Senam lansia yaitu aerobic low impact mencakup latihan peregangan yang kemudian dapat meningkatkan elastisitas dan panjang otot serta jaringan disekitar sendi sehingga mampu meningkatkan fleksibilitas. ${ }^{12}$ Menurut penelitian oleh Lanawati tahun 2015, senam kesegaran jasmani lansia dapat menghambat gangguan keseimbangan tubuh dan penurunan fungsi kognitif dan lansia. Proporsi lansia yang mempunyai fungsi kognitif yang normal lebih besar pada lansia yang rutin mengikuti senam lansia serta memiliki peluang keseimbangan tubuh yang baik lebih besar. Hasil penelitian tersebut meperlihatkan bahwa lansia yang rutin mengikuti senam lansia mempunyai keseimbangan yang lebih baik di bandingkan lansia yang tidak mengikuti senam lansia. ${ }^{15}$ Serupa dengan penelitian oleh Prasetyo tahun 2015, menyatakan bahwa ada pengaruh yang terjadi pada lansia yang mengikuti Senam Sehat Indonesia (aerobic low impact) terhadap keseimbangan tubuh lansia. Senam aerobic low impact memacu otot-otot untuk bergerak. Gerakan yang terprogram dan terpola kemudian secara fisiologis akan memberikan respon adaptif pada sistem muskuloskeletal. Respon otot-otot postural yang sinergis akan meningkat apabila kemampuan otot besar memiliki performa yang baik. Pada tungkai, gerakan dari senam akan meningkatkan kemampuan dan kekuatan otot tungkai untuk mempertahankan keseimbangan. ${ }^{5}$

Berdasarkan dari hasil penelitian, terdapat hubungan antara fleksibilitas lumbal dengan keseimbangan dinamis pada lansia yang mengikuti senam lansia di Desa Sumerta Kelod Denpasar Timur yang dilakukan dengan uji statistik Chi Square dengan nilai Asymptotic Significance (2-sided) atau p yang diperoleh sebesar 0,000 dimana nilai $\mathrm{p}$ lebih kecil dari 0,05, maka $\mathrm{HO}$ ditolak dan Ha diterima, artinya terdapat hubungan antara fleksibilitas lumbal dengan keseimbangan dinamis pada lansia di Desa Sumerta Kelod Denpasar Timur. Hal ini sejalan dengan penelitian dari Sari tahun 2015 menunjukan menyatakan bahwa lansia yang memiliki fleksibilitas trunk baik mempunyai keseimbangan yang baik dengan kemungkinan $7 x$ lebih besar. Hal tersebut dilihat dari nilai $p=0,001$, dengan odd ratio $(O R)=7,42$. Sehingga dapat disimpulkan antara fleksibilitas trunk dengan keseimbangan pada lanjut usia terdapat hubungan yang positif. ${ }^{19}$

Perubahan biologis seperti kekakuan tendon, perubahan kapsul sendi, atau perubahan otot dinyatakan bertanggung jawab terhadap adanya penurunan fleksibilitas yang berkaitan dengan usia. ${ }^{11}$ Beberapa penelitian menemukan adanya hubungan antara perubahan struktur lumbar dengan kinerja keseimbangan yang lebih buruk diukur dengan stabilometri dan peningkatan kejadian jatuh pada lansia sehat. Perubahan pada lumbal akan mengakibatkan hilangnya lordosis lumbal sehingga terjadi penurunan fleksibilitas pada lumbal. Hilangnya lordosis lumbal menyebabkan retroversi panggul dan pergeseran posterior garis gravitasi. ${ }^{20}$ Hilangnya lordosis lumbal meningkatkan ketidakstabilan postur dan kecenderungan untuk jatuh pada orang dewasa dengan osteoporosis. Hal tersebut disebabkan karena hilangnya lordosis lumbal maupun hiperkyphosis thoracic akan menginduksi perpindahan garis gravitasi dalam bidang sagital, mengurangi batas stabilitas di semua arah serta besarnya respon dan kecepatan perpindahan terutama di sumbu antero-posterior. ${ }^{20}$

Penurunan fleksibilitas dapat menyebabkan timbulnya masalah seperti kesulitan berjalan, kesulitan beraktivitas, kelemahan dan adanya nyeri. Respon keseimbangan yang efektif dapat terjadi apabila adanya fleksibilitas disertai dengan struktur mekanik yang cukup. Berkurangnya fleksibilitas disebabkan oleh berkurangnya volume diskus dan kolagen dalam annulus berubah akibat dari kadar air nukleus pulposus berkurang sehingga sendi kurang fleksibel. Salah satu komponen yang penting bagi kebugaran fisik dan kesehatan yaitu fleksibilitas sendi. Penurunan efektifitas dan efisiensi dalam mempertahankan keseimbangan dapat disebabkan karena berkurangnya fleksibilitas. ${ }^{8}$

Strategi kontrol gerakan yang digunakan ketika menggerakkan pusat massa kedepan adalah dengan cepat berubah dari ankle strategy ke hip strategy dengan hip joint sebagai poros gerak. Ketika menekuk vertebra lumbal maka secara kooperatif diikuti fleksi hip joint, hal ini jelas menunjukkan bahwa kelenturan fleksi vertebra lumbal berkontribusi dalam menggerakkan pusat massa ke depan. Ketika fase terminal pada siklus berjalan, posisi hip joint ekstensi dengan kata lain posisi pelvis cenderung backward dan ekstensi trunk relatif kearah femur yang kemudian menggerakan kaki berayun ke depan. Kelenturan seluruh tulang belakang, yaitu rentang kelenturan vertebra toraks dan vertebra lumbar ditambah backward dari pelvis akan diperlukan selama fase berjalan. Oleh karena itu, semakin besar rentang kelenturan 
seluruh tulang belakang, maka semakin lebar langkah saat berjalan. Sehingga mobilitas tulang belakang pada bidang sagital berkorelasi dengan kemampuan keseimbangan dinamis, yang terkait dengan jatuh. ${ }^{21}$ Apabila fleksibilitas lumbal menurun, maka akan terjadi perubahan postural alignment pada pusat gravitasi tubuh yaitu adanya kompensasi pada pergeseran berat tubuh ke arah vertikal kedepan tumit sehingga tidak berada pada landasan penunjang. Sehingga tubuh tidak mampu mempertahankan keseimbangan posturnya. ${ }^{19}$ Adanya perubahan tersebut menyebabkan menurunnya kemampuan tubuh dalam menjaga keseimbangan posturak pada lansia. Kelompok umur lansia mempunyai resiko yang paling tinggi mengalami gangguan keseimbangan. ${ }^{2}$

\section{SIMPULAN}

Berdasarkan dari hasil penelitian, maka dapat disimpulkan bahwa terdapat hubungan antara fleksibilitas lumbal dengan keseimbangan dinamis pada lansia usia 60-74 tahun yang mengikuti senam lansia di Desa Sumerta Kelod Denpasar Timur.

\section{DAFTAR PUSTAKA}

1. Chiacchiero, M., 2010. The Relationship Between Range Of Movement, Flexibility, And Balance In The Elderly. Topics In Geriatric Rehabilitation, Volume 26 (2), Pp. 147-154.

2. Miller., 2004. Nursing For Wellness In Older Adult Theory And Practice. Philadelpia.

3. Riskesdas., 2013. Riset Kesehatan Dasar Nasional. www.depkes.go.id/Resources/Download/General/Hasil\%20Riskesdas\%202013.Pdf

4. Manangkot, M.V., 2016. Pengaruh Senam Lansia Terhadap Keseimbangan Tubuh Pada Lansia Di Lingkungan Dajan Bingin Sading. Nursing Program, School of Medicine, Udayana University

5. Prasetyo, A, \& Nanang, I., 2015. Peningkatan Keseimbangan Postural Menggunakan Pengukuran Berg Balance Scale (BBS) pada Lansia di Sasana Panti Mulyo Sragen. Journal of Sport Sciences and Fitness, 4(1).

6. Sheylla, S.M., 2015. Perbedaan Tingkat Keseimbangan Tubuh Antara Lansia Yang Mengikuti Senam Dengan Lansia Yang Tidak Mengikuti Senam Di Yayasan Gerontologi Kecamatan Wajak Kabupaten Malang. Jurnal Wiyata, Vol. 2

7. Egwu, M.O., Mbada, C.E. \& Olowosejeje, D., 2012. Normative Values Of Spinal Flexibility For Nigerians Using The Inclinometric Technique. Journal Of Exercise Science And Physiotherapy, Vol. 8, No. 2: 93-104.

8. Stanley, M \& Patricia, G. B., 2007. Buku Ajar Keperawatan Gerotik. Edisi 2. Ed. Meiliya Eni Dan Ester Monika, Jakarta : Kedokteran EGC

9. Septiana, Y., 2014. Pengaruh Pemberian Core Stability Exercise Dengan Metode Pilates Exercise Terhadap Keseimbangan Dinamis Pada Anggota Posyandu Lansia Bagas Waras Colomadu. Naskah Publikasi. Universitas Muhammadiyah Surakarta.

10. Dewi, A. A. N. T. N., 2015. Perbedaan Aquatic Exercise Therapy Dan Senam Aerobic Low Impact Dalam Meningkatkan Keseimbangan Dinamis Pada Lansia Di Banjar Dharma Santi Denpasar. Tesis. Denpasar: Unud.

11. Adams, K, O'Shea, P, O'Shea, Katie, L.M.S.,1999. Aging: Its Effects on Strength, Power, Flexibility, and Bone Density. Strength and Conditioning Journal, Volume 21(2) : 65-77

12. Percusha, O.Z., 2017. Pengaruh Senam Aerobic Low Impact Terhadap Fleksibilitas Lumbal Pada Wanita Lanjut Usia Di Panti Wredha Dharma Bakti Surakarta. Program Studi Fisioterapi Fakultas IImu Kesehatan Universitas Muhammadiyah Surakarta

13. Yanti, A.D., \&, Armayanti, L., 2016. Hubungan Keaktifan Senam Lansia Dengan Keseimbangan Tubuh Pada Lansia Di Panti Werdha Majapahit Mojokerto. STIKes Bina Sehat PPNI Mojokerto, Jawa Timur

14. Stathokostas, Liza \& Theou, Olga \& Little, Rob \& Vandervoort, A \& Raina, Parminder., 2013. Physical ActivityRelated Injuries in Older Adults: A Scoping Review. Sports medicine (Auckland, N.Z.). 43. 10.1007/s40279-0130076-3.

15. Lanawati, Listyowati, R., Kuswardhani, R.A.T., 2015. Hubungan antara Senam Kesegaran Jasmani dengan Fungsi Kognitif dan Keseimbangan Tubuh Lansia di Denpasar. Public Health and Preventive Medicine Archive 3(2): 168172. DOI:10.15562/phpma.v3i2.111

16. Wijianto., 2013. Perbedaan Pengaruh Senam Kesegaran Jasmani Lanjut Usia Dan Senam Yoga Terhadap Peningkatan Keseimbangan Dinamis Ditinjau Dari Indeks Massa Tubuh (Studi Experimen Pada Anggota Pusat Pelayanan Terpadu Lanjut Usia Colomadu ).

17. Dunsky, A., Zeev, A., \& Netz, Y., 2017. Balance Performance Is Task Specific In Older Adults. Biomed Research International, 6987017.

18. Rahal, M. A., Alonso, A. C., Andrusaitis, F. R., Rodrigues, T. S., Speciali, D. S., Greve, J. M., \& Leme, L. E., 2015. Analysis of static and dynamic balance in healthy elderly practitioners of Tai Chi Chuan versus ballroom dancing. Clinics (Sao Paulo, Brazil), 70(3), 157-161.

19. Sari., 2015. Hubungan Antara Fleksibilitas Trunk Dengan Keseimbangan Pada Lanjut Usia. Naskah Publikasi. Universitas Muhammadiyah. Surakarta.

20. Fernandes, V. L. S., Ribeiro, D. M., Fernandes, L. C., \& Menezes, R. L. De., 2018. Postural changes versus balance control and falls in community-living older adults: a systematic review. Fisioterapia Em Movimento, 31(0).

21. Takeuchi, Y., 2017. Sagittal Plane Spinal Mobility is Associated With Dynamic Balance Ability Of CommunityDwelling Elderly People. J. Phys. Ther. Sci. 29: 112-114.

22. Sulaiman \& Anggriani., 2018. Efek Postur Tubuh Terhadap Keseimbangan Lanjut Usia Di Desa Suka Raya Kecamatan Pancur Batu. Jurnal JUMANTIK Vol. 3 No.2 